\title{
PROPERTIES OF MULTICOMPONENT BIOFUEL BLENDS, CONTAINING RAPESEED OIL BUTYL ESTERS, BIOBUTANOL AND FOSSIL DIESEL FUEL
}

\author{
Irina Kazanceva, Eglè Sendžikienė, Milda Gumbytė, Kiril Kazancev \\ Aleksandro Stulginskio university \\ E-mail: agrotech@asu.lt
}

Received 2014-06-12, accepted 2014-09-12

\begin{abstract}
Chemical and physical properties (density, kinematic viscosity, flash point, copper strip corrosion, calorific value) of multicomponent biofuel blends, containing rapeseed oil butyl or methyl esters, biobutanol and fossil diesel fuel are discussed in this paper. Ester, water and partial glycerides contents were determinated in multicomponent biofuel blends. These properties were compared with the same properties of pure biodiesel (rapeseed oil butyl and methyl esters) and pure diesel fuel. As there are no standards for blends fuel, containing more than $7 \%$ of biocomponents, that is why, density and viscosity were evaluated according standards EN 14214 and EN 590.

It is determined that the addition of butanol and rapeseed oil butyl esters should improve the cold flow properties, such as cloud point and cold filter plugging point.

As rapeseed oil butyl esters were produced from high acidity rapeseed oil (4\%), much attention was deviated for oxidation stability and acidity of pure rapeseed oil butylesters and it blends with butanol and diesel fuel.

Rapeseed oil butyl esters, rapeseed oil methyl esters, properties, cold flow properties, oxidation stability, acidity.
\end{abstract}

\section{Introduction}

Nowadays, the world is looking for alternative energy sources for replacement of the fossil diesel. One of these sources could be biodiesel, which is derived from renewable resources. Traditionally biodiesel is produced from fatty raw material, for example, rapeseed oil (Europe), soybean oil (USA), palm oil (Asia) by transesterification reaction (Atabani et al, 2012). As transesterification process is quite slow, it is important to use a catalyst for transesterification reaction. The alkaline catalysts $\left(\mathrm{KOH}, \mathrm{NaOH}, \mathrm{H}_{2} \mathrm{SO}_{4}\right.$ etc) are commonly used in industry. The application of biotechnological methods with usage of lipases as catalysts is important because these methods are environmentally friendly; the synthesis conditions are mild; it is ease to separate catalyst from product; differently from alkaline catalysis, soaps are not forming during enzymatic catalysis (Fjerbaek et al., 2009). In compare with traditional catalysts, the usage of lipase for biodiesel synthesis is not widely investigated. Recently the biotechnological method is installed in factories (2007 - Lvming Co.Ltd in China, 
2010 - Piedmont Biofuels with Novozymes in USA) (Tan et. al., 2010). In biodiesel synthesis vegetable oil is transesterified with alcohol, the most widespread is methanol. However, methanol has disadvantages: it has high toxicity, can be absorbed through the skin and is synthesized from non-renewable sources. Ethanol and other higher alcohols could be also used for biodiesel synthesis. Ethanol and biobutanol are derived from agricultural products (corn stover, wheat straw and so on), so it is renewable, besides it is safer to handle. Therefore, biodiesel fuel produced by transesterification with butanol is completely renewable (M. Kumar, K. Gayen, 2011). Biobutanol can be used in biofuel production for fat or oil transesterification and/or as additional component in the fuel mixture.

There are no many data about properties and application possibilities of rapeseed oil fatty acid butylesters (RBE). Physical and chemical properties of fuel are very important for using in engine vehicle. Standards such as EN 14214 and EN 590 control quality of fatty acid methyl esters (FAME) and mineral diesel fuel respectively. One of the important properties for using fuel are cold flow properties: cold point (CP) and cold filter plugging point (CFPP). According to the EN 14214 and EN 590 standards, temperate climatic zones are divided in classes from $\mathrm{A}\left(+5^{\circ} \mathrm{C}\right)$ to $\mathrm{F}\left(-20^{\circ} \mathrm{C}\right)$, the difference between temperature of class is minus five degrees. The arctic climatic zones has 4 classes from $0\left(-20{ }^{\circ} \mathrm{C}\right)$ to $4\left(-44{ }^{\circ} \mathrm{C}\right)$, the difference between temperature of class is minus six degrees. Under this classification Lithuania belongs to temperate zone (CFPP in winter (from November 16 to March 15) is of 2 class of arctic climatic zone, in transition period (from March 16 to April 30 and from October 1 and November 15) - E class and in summer - C class). CFPP value depends on ester composition: fatty acid chain length, number and position of double bonds, unsaturated groups, isomerization. As butyl carbon chain is longer than ethyl- and methyl, CFPP of butylesters expected to be lower than methylesters. Researchers Bouaid and other (2014) have investigated cold flow properties of rapeseed oil and used for frying oil butylesters. They determined that CFPP of RBE is minus $21^{\circ} \mathrm{C}, \mathrm{CP}$ - minus $8{ }^{\circ} \mathrm{C}$ (Bouaid et al., 2014). The properties of multicomponent blends, consisting of butanol, RBE and mineral diesel, are not studied. However, it is expected, that cold flow properties should be better than neat RBE because of lower CFPP of butanol (minus $36^{\circ} \mathrm{C}$ ).

The aim of our studies was to evaluate physical and chemical properties of multicomponent fuel, containing rapeseed oil butylesters (RBE), fossil diesel and biobutanol are not widely described, according to the requirements of standard LST EN 14214 and comparing with multicomponent fuel, containing rapeseed oil methylesters (RME), fossil diesel and biobutanol.

\section{Materials and methods}

RBE were produced in laboratory from acid rapeseed oil with acidity $4 \%$, RME were purchased from JSC "Mestilla", diesel fuel (for arctic climatic zone, 
class 1), meeting with standard EN 590 requirements - from local distributer. Butanol 99.5\% was purchased from Aldrich.

Multicomponent biofuel were made from diesel fuel, biodiesel (rapeseed oil methyl and butyl esters) and butanol: RBE15B15D70 consists of 15\% RBE, 15\% butanol, 70\% diesel fuel (v/v/v); RME15B15D70 consists of 15\% RME, 15\% butanol, 70\% diesel fuel (v/v/v); RBE25B25D50 consists of 25\% RBE, 25\% butanol, 50\% diesel fuel (v/v/v); RME25B25D50 consists of 25\% RME, 25\% butanol, $50 \%$ diesel fuel (v/v/v).

Content of glycerides (glycerol, monoglycerides, diglycerides, and triglycerides) in biodiesel samples were analyzed with the gas chromatograph Perkin Elmer Clarus 500 (detector - FID) according to the requirements of standard LST EN 14105. The gas chromatography method specified in the standard LST EN 14103 was applied for the determination of ester content. Density and viscosity were measured with the viscometer Stabinger SVM 3000. Density was measured according to the requirements of the standard EN ISO 12185. Viscosity was measured according to the requirements of the standard EN ISO 3104. Acidity was measured according to EN ISO 660. Water content was measured according to the standard EN ISO 12937 requirements, oxidation stability - by Rancimat method EN14214, acid value - by using analyzer Titrino plus according to the requirements of standard EN 14104:2003. For the performance of CFPP (cold filter plugging point) tests, the thermostatic bath PROLINE RP-845 (LAUDA, Germany) was used. CFPP was determined according to the requirements of standard EN 116. The calorific value was measured by using IKA C2000 calorimeter according to the requirements of ISO 1928. Copper strip corrosion was evaluated according to the requirements of standard EN ISO 2160. All data are the average of 3 measures.

The quality of fuel is limited by standards, such as EN 14214 (European Standard that describes the requirements and test methods for fatty acid methylesters), EN 590 (describes the physical and chemical properties of automotive diesel sold in the European Union, Croatia, Iceland, Norway and Switzerland.). There are no standard, determining the quality of fatty acid butylesters and biodiesel blends with fossil diesel fuel. That is why; the results of experiments are evaluated taking into account both standard EN 14214 and EN 590.

\section{Results and discussion}

According to standard EN 590, it is possible to insert till $7 \%$ of biodiesel in diesel fuel, but it is determined, that addition of biodiesel up to $30 \%$ would improve environmental impact (Makarevičienè et al., 2013). Therefore, we investigated the mixture containing $30 \%$ of biofuel $(15 \% \mathrm{RBE}$ and $15 \%$ biobutanol) and $70 \%$ mineral diesel as well as the mixture containing $50 \%$ of biofuel (25\% RBE and 25\% biobutanol). To compare results we investigated the mixtures containing RME and fossil diesel in the same proportion.

The physical and chemical properties are important for using fuel. Density, viscosity of fuel mixtures are presented in the Table 1. 
Table 1. Physical and chemical properties of fuel mixtures

\begin{tabular}{|l|c|c|c|c|c|c|c|}
\hline Parameter & $\begin{array}{c}\text { Limits } \\
\text { according } \\
\text { to EN } \\
14214\end{array}$ & $\begin{array}{c}\text { RBE15 } \\
\text { B15D70 }\end{array}$ & $\begin{array}{c}\text { RBE25 } \\
\text { B25D50 }\end{array}$ & $\begin{array}{c}\text { RME15 } \\
\text { B15D70 }\end{array}$ & $\begin{array}{c}\text { RME25 } \\
\text { B25D50 }\end{array}$ & RBE & RME \\
\hline $\begin{array}{l}\text { Viscosity, } \\
\mathrm{mm}^{2} / \mathrm{s}\end{array}$ & $\begin{array}{c}\text { Min. 3.5, } \\
\text { max. 5 }\end{array}$ & 2.18 & 2.38 & 2.09 & 2.25 & 5.48 & 4.62 \\
\hline $\begin{array}{l}\text { Density, } \\
\mathrm{kg} / \mathrm{m}^{3}\end{array}$ & $\begin{array}{c}\text { Min. 860, } \\
\text { max. 900 }\end{array}$ & 834 & 837 & 835 & 839 & 873 & 884 \\
\hline
\end{tabular}

As we can see from data shown in the table 1, both parameters viscosity and density of multicomponent blends don't meet the requirements of standard EN 14214. Though the values of density of the pure biofuel are in the limits presented in the standard, but RBE, because of its bigger molecular mass and longer carbon chain, is more viscous in compare with RME. Researchers Knothe and Steidley investigated kinematic viscosity of fatty acid alkyl esters (Knothe, Steidley, 2007). They determined, that butylesters of lauric, oleic, linoleic and linolenic acids specify such kinematic viscosity $\left(\right.$ at $\left.40{ }^{\circ} \mathrm{C}\right) 3.36,5.63,4.94 \mathrm{~mm}^{2} / \mathrm{s}$ respectively. Our results meet with their obtained results for oleic acid butylesters. Other researchers (Bouaid et al., 2014), found out that viscosity value of RBE equals to $4.89 \mathrm{~mm}^{2} / \mathrm{s}$.

As standard EN 14214 present the quality requirements for pure biodiesel, we analysed physical and chemical properties of fuel mixtures containing fossil diesel, biodiesel and butanol and evaluated their conformity to the requirements of standard EN 590 (table 2). According to the requirements of above-mentioned standard, viscosity and density of diesel fuel for temperate climatic zone are not the same as for arctic climatic zones.

Table 2. Requirements of standard EN 590 for physical and chemical properties of diesel fuel

\begin{tabular}{|c|c|c|c|c|c|c|c|c|c|c|c|}
\hline \multicolumn{7}{|c|}{ Temperate climatic zones } & \multirow{2}{*}{\multicolumn{5}{|c|}{$\frac{\text { Arctic climatic zones }}{\text { Class }}$}} \\
\hline \multirow{2}{*}{ Property } & \multicolumn{6}{|c|}{ Class } & & & & & \\
\hline & $\mathbf{A}$ & B & $\mathbf{C}$ & D & $\mathbf{E}$ & $\mathbf{F}$ & 0 & 1 & 2 & 3 & 4 \\
\hline $\mathrm{CFPP},{ }^{\circ} \mathrm{C}$ & +5 & 0 & -5 & -10 & -15 & -20 & -20 & -26 & -32 & -38 & -44 \\
\hline $\begin{array}{l}\text { Density at } \\
15^{\circ} \mathrm{C}, \mathrm{kg} / \mathrm{m}^{3}\end{array}$ & \multicolumn{6}{|c|}{$820-860$} & \multicolumn{3}{|c|}{$800-845$} & \multicolumn{2}{|c|}{$800-840$} \\
\hline $\begin{array}{l}\text { Viscosity at } \\
40^{\circ} \mathrm{C}, \mathrm{mm}^{2} / \mathrm{s}\end{array}$ & \multicolumn{6}{|c|}{$2-4.5$} & \multicolumn{3}{|c|}{$1.5-4.0$} & $1.4-4.0$ & $1.2-4.0$ \\
\hline $\mathrm{CP},{ }^{\circ} \mathrm{C}$ & & & & & & & -10 & -16 & -22 & -28 & -34 \\
\hline
\end{tabular}

Comparing the data presented in the Table 1 and Table 2 , it is obviously that densities and viscosities of blends are in the limits of standard EN 590. Cold flow properties of fuel mixtures are presented in the Figure 1. 


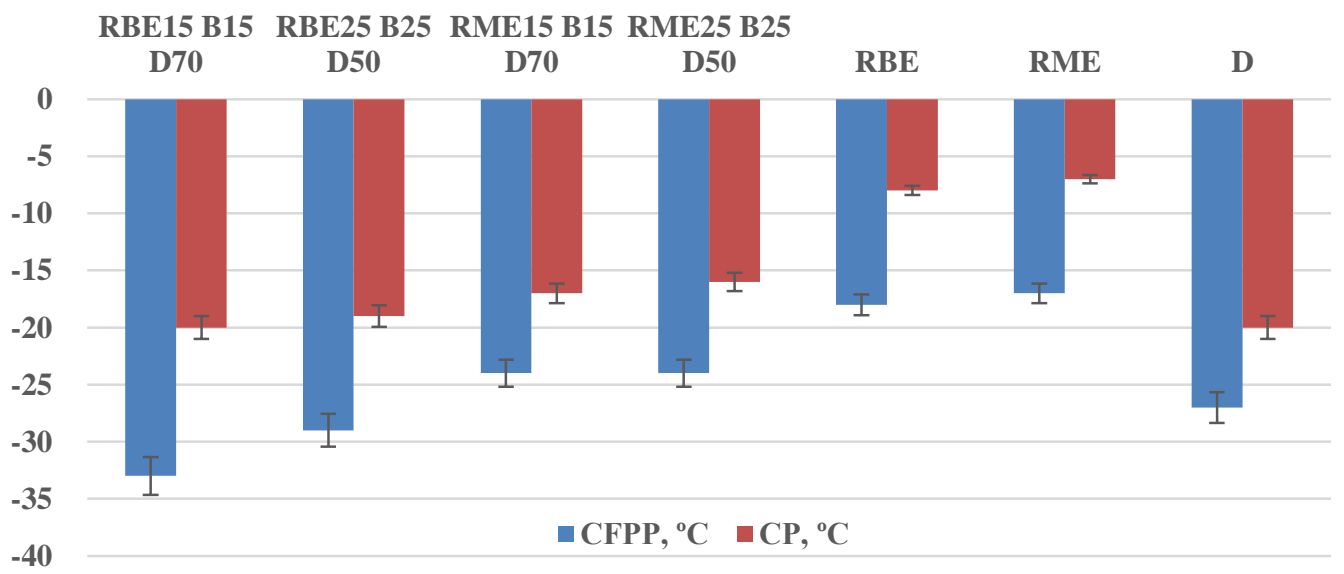

Fig. 1. CFPP and CP of multicomponent fuel blend, pure biodiesel and diesel fuel

The data presented in the Figure 1 show that $\mathrm{CP}$ of pure diesel fuel, $\mathrm{RBE}$ and $\mathrm{RME}$ are respectively minus $20^{\circ} \mathrm{C}$ (class 1 of arctic climatic zone), minus $8{ }^{\circ} \mathrm{C}$, minus $7{ }^{\circ} \mathrm{C}$. It is a tendency, that increasing part of biofuel in the blends, $\mathrm{CP}$ increases: CP of RBE $15 \mathrm{~B} 15 \mathrm{D} 70$ is minus $20^{\circ} \mathrm{C}$, RBE $25 \mathrm{~B} 25 \mathrm{D} 50-$ minus $19^{\circ} \mathrm{C}$, RME 15 B15 D70 is minus $17{ }^{\circ} \mathrm{C}$, RME 25 B25 D50 - minus $16{ }^{\circ} \mathrm{C}$. So, all blends belong to class 1 of arctic climatic zone by $\mathrm{CP}$.

CFPP of all tested fuel is less than minus $15{ }^{\circ} \mathrm{C}$. So, all kinds of fuel could be used in temperate climatic E zone. Analyzing the data presented in the Tables 1 and 2 as well as in Figure 1, it could be concluded, that tested fuel mixtures could be also used in arctic zone: blends containing 15\% RBE meet the requirements for 2 class, blends containing 25\% RBE - requirements of 1 class, blends with RME - of 0 class. Our results of $\mathrm{CP}$ are completely consistent with the results of Bouaid (Bouaid, 2014), but values of CFPP is little higher. CFPP of pure RBE is 1 degree lower than RME (respectively, minus 18 and minus $17^{\circ} \mathrm{C}$ ), pure diesel minus $27^{\circ} \mathrm{C}$. CFPP of multicomponent biofuel blends, containing RBE, are lower than of pure diesel. CFPP of butanol is minus $36{ }^{\circ} \mathrm{C}$, so butanol addition leads to decreasing CFPP of multicomponent biofuel blends by approximately 10 degrees.

$\mathrm{CP}$ of pure diesel fuel, RBE and RME are respectively minus $20^{\circ} \mathrm{C}$, minus $8{ }^{\circ} \mathrm{C}$, minus $7^{\circ} \mathrm{C}$. It is a tendency, that increasing part of biofuel in the blends, $\mathrm{CP}$ increases (CP of RBE 15 B15 D70 is minus $20^{\circ} \mathrm{C}$, RBE $25 \mathrm{~B} 25 \mathrm{D} 50$ - minus $19{ }^{\circ} \mathrm{C}$, RME $15 \mathrm{~B} 15 \mathrm{D} 70$ is minus $17^{\circ} \mathrm{C}$, RME $25 \mathrm{~B} 25 \mathrm{D} 50$ - minus $16{ }^{\circ} \mathrm{C}$.

Table 3 shows the other physical and chemical properties of multicomponent fuel as well as requirements of standard EN 14214 for biodiesel. 
Table 3. Physical and chemical properties of fuel

\begin{tabular}{|c|c|c|c|c|c|c|c|}
\hline Properties & $\begin{array}{c}\text { EN } \\
14214 \\
\end{array}$ & RBE15B15D70 & RBE25B25D50 & RME15B15D70 & $\begin{array}{c}\text { RME25B25 } \\
\text { D50 } \\
\end{array}$ & RBE & RME \\
\hline $\begin{array}{l}\text { Ester content, } \\
\%\end{array}$ & $\begin{array}{l}\text { Min. } \\
96.5\end{array}$ & 14.96 & 24.93 & 14.67 & 24.45 & 99.74 & 97.80 \\
\hline $\begin{array}{l}\text { Monoglycerid } \\
\text { es content, \% } \\
\text { (of mass) }\end{array}$ & $\begin{array}{c}\text { Max. } \\
0.8\end{array}$ & 0.09 & 0.14 & 0.08 & 0.14 & 0.57 & 0.56 \\
\hline $\begin{array}{l}\text { Diglycerides } \\
\text { content, \% } \\
\text { (of mass) }\end{array}$ & $\begin{array}{c}\text { Max. } \\
0.2\end{array}$ & 0.01 & 0.01 & 0.03 & 0.05 & 0.04 & 0.2 \\
\hline $\begin{array}{l}\text { Triglycerides } \\
\text { content, \% } \\
\text { (of mass) }\end{array}$ & $\begin{array}{c}\text { Max. } \\
0.2\end{array}$ & 0 & 0 & 0 & 0 & 0.01 & 0.01 \\
\hline $\begin{array}{l}\text { Free glycerol } \\
\text { content, } \% \\
\text { (of mass) }\end{array}$ & $\begin{array}{c}\text { Max. } \\
0.02\end{array}$ & 0 & 0 & 0 & 0 & 0 & 0 \\
\hline $\begin{array}{l}\text { Total glycerol } \\
\text { content, \% } \\
\text { (of mass) }\end{array}$ & $\begin{array}{c}\text { Max. } \\
0.25\end{array}$ & 0.02 & 0.04 & 0.03 & 0.05 & 0.154 & 0.19 \\
\hline $\begin{array}{l}\text { Water } \\
\text { content, } \\
\mathrm{mg} / \mathrm{kg}\end{array}$ & $\begin{array}{l}\text { Max. } \\
500\end{array}$ & 112.82 & 131.38 & 190.81 & 214.7 & 268.642 & 283.22 \\
\hline $\begin{array}{l}\text { Flash point, } \\
{ }^{\circ} \mathrm{C}\end{array}$ & $\begin{array}{l}\text { Min. } \\
101\end{array}$ & 41 & 40 & 44 & 46 & 202 & 186 \\
\hline $\begin{array}{l}\text { Copper strip } \\
\text { corrosion } \\
\left(3 \mathrm{~h} \text { at } 50^{\circ} \mathrm{C}\right)\end{array}$ & $\begin{array}{c}\text { Class } \\
1\end{array}$ & \multicolumn{6}{|c|}{ Class 1} \\
\hline $\begin{array}{l}\text { Calorific } \\
\text { value }\end{array}$ & & 43449 & 41971 & 43145 & 41730 & 405993 & 39763 \\
\hline
\end{tabular}

According to the requirements of biodiesel standard EN 14214, the monoglycerides content should be lower than $0.8 \%$, diglycerides and triglycerides contents each lower than $0.2 \%$. In addition, the ester content should be greater than or equal to $96.5 \%$. As we can see, for RBE and RME the ester content are $99.74 \%$ and $97.80 \%$ respectively. As for partial glycerides, for both samples of esters they are in the range of the standard.

Water content in pure biodiesel should be no higher than $500 \mathrm{mg} / \mathrm{kg}$, as we can see from table 1, pure biofuel as well as multicomponent blends are in the range from 112 to $283 \mathrm{mg} / \mathrm{kg}$.

The analysis of copper strip corrosion $\left(3 \mathrm{~h}\right.$ at $\left.50{ }^{\circ} \mathrm{C}\right)$ shows that all fuel (blends and pure biofuel) meet the requirements of 1 class.

Flash point of the pure biofuel exceeds the requirements of standard EN 14214. The standard is determined the flash point to be higher than 101. The flash points of pure RBE and RME are 202 and $186{ }^{\circ} \mathrm{C}$ respectively. As for multicomponent fuel, flash points are lower - from 40 to $46^{\circ} \mathrm{C}$.

Calorific value of pure RBE as well as multicomponent fuel with RBE is higher than respective fuel containing RME. 
Oxidation stability is one of the important properties of biodiesel. Biodiesel autoxidation can begin during biodiesel storage, when esters (methyl or butyl) contact with oxygen, forming peroxides, aldehydes, acids (Karavalakis et al., 2010). These substances can negatively affect engine performance by blocking filters and injectors and forming corrosive environment for fuel injection equipment. Besides biodiesel degradation due to auto-oxidation can cause to change biofuel properties, such as flash point, ester content, heating value, cetane number, kinematic viscosity and density as well as acidity (Pullen, Saeed, 2014). Therefore, we investigate the oxidation stability of multicomponent biofuel blends and pure biodiesel as well as diesel fuel. The results of fuels oxidation stability evaluation are presented in the Figure 2.

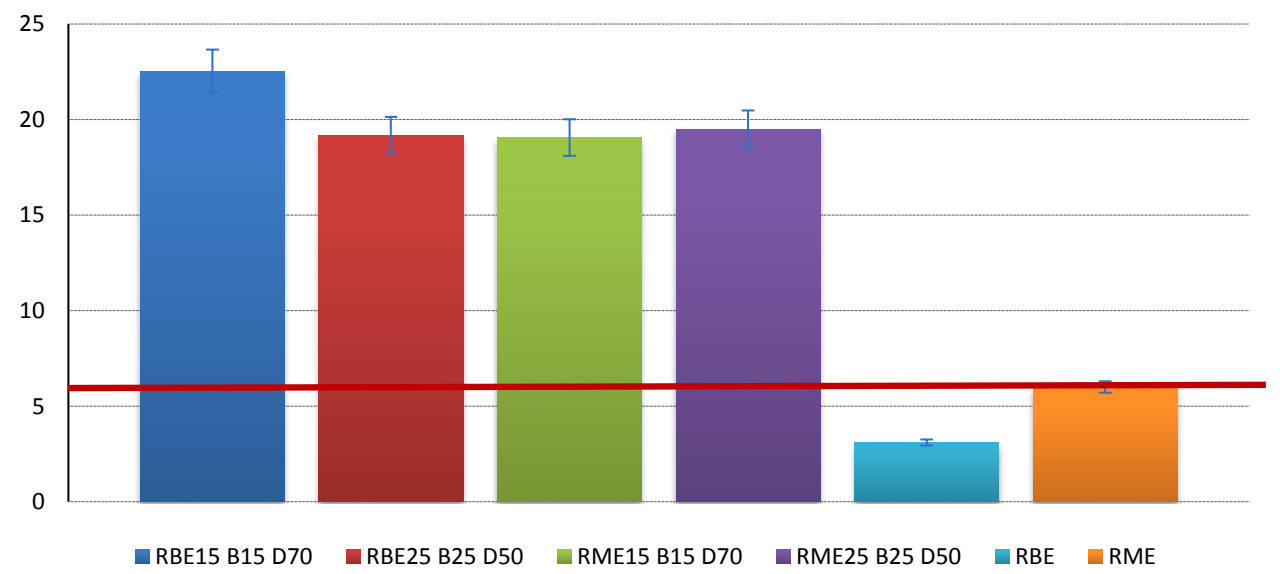

Fig. 2. Oxidation stability of multicomponent fuel and pure biofuel

According to standard EN 14214 requirements, the oxidation stability of biodiesel should be not less than $6 \mathrm{~h}$. As the data shown in the Fig.2, only pure RBE has low oxidation stability (only $3 \mathrm{~h}$ ). As for multicomponent fuel, blends with RBE as well as with RME are characterized by high oxidation stability. For increasing the oxidation stability of pure RBE the effective antioxidants should be used.

Acid value is directly related to stability, though this parameter is not used for stability evaluation. Acid value quantifies the amount of acid, which appear during oxidation, in biodiesel. High acid value of biodiesel could lead to corrosion of engine and fuel containers. It is very important to be lower $0,5 \mathrm{mg} / \mathrm{g} \mathrm{KOH}$. As we investigate acid value of multicomponent fuel blends, consisting RBE, which is derived from acid rapeseed oil (which acidity is $4 \%$ ), the acid value is very important.

The investigation of acid value results are shown in the figure 3. 


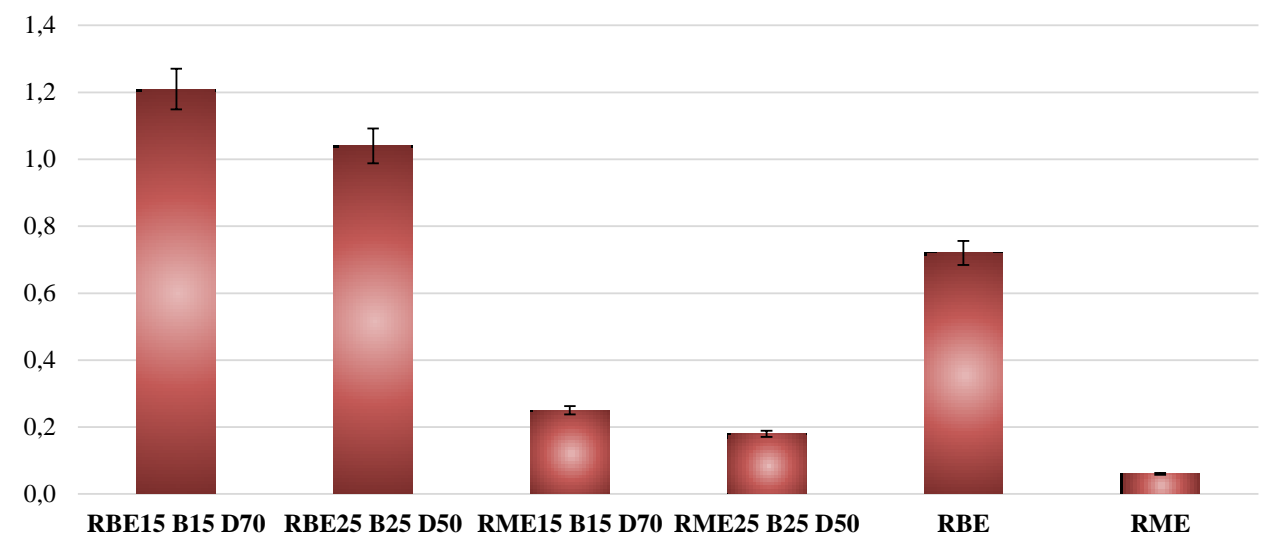

Fig. 3. Acid value of multicomponent fuel blends and pure biodiesel

According to the standard EN 14214 requirements acid value of biodiesel should not be higher than 0.5. Acid value of RBE is higher - 0.7. Because of this fact, the blends fuel with RBE are characterized with high acid value. In contrary RME acid value is 0.06 , the blends with RME has acid value, which meet with standard requirements.

\section{Conclusions}

Some parameters don't meet the requirements of standard EN 14214 (for pure FAME), such as density and viscosity of multicomponent fuel blend consisting RBE and pure RBE, but coincide standard EN 590 (for diesel fuel). $\mathrm{RBE}$ and blends with RBE are characterized with low CFPP (minus 18 - minus 33). Multicomponent blends containing 15\% RBE meet the requirements for 2 class of arctic climatic zone, blends containing 25\% RBE - requirements of 1 class of arctic climatic zone, blends with RME - of 0 class of arctic climatic zone. All kinds of fuel could be used in temperate climatic E zone. All blends belong to class 1 of arctic climatic zone by CP. So, RBE and butanol addition improve cold flow properties.

According to the requirements of biodiesel standard EN 14214, partial glycerides, ester, total and free glycerol, water content are in the range of the standard. The analysis of copper strip corrosion shows that all fuel meet the requirements of 1 class. Flash point of the pure biofuel exceeds the requirements of standard EN 14214, in contrary flash point of multicomponent fuel, flash points are lower - from 40 to $46{ }^{\circ} \mathrm{C}$. Calorific value of pure RBE as well as multicomponent fuel with RBE is higher than respective fuel containing RME. Oxidation stability of the blends with RBE and RME meet with standard EN 14214 requirements, but pure RBE needs antioxidants. Acid value of RBE and its blends exceed limits of standard EN 14214, while RME and its blends meet requirements of standard EN 14214. 


\section{Acknowledgements}

The research was funded by a project (MIP-028/2013) from the Research Council of Lithuania.

\section{References}

1. Atabani A.E., Silitonga A.S., Badruddin I.A., Mahlia T.M.I., Masjuki H.H., Mekhilef S. 2012. A comprehensive review on biodiesel as an alternative energy resource and its characteristics. Renewable and Sustainable Energy Reviews, 16 (4), 2070-2093. DOI: 10.1016/j.rser.2012.01.003.

2. Bouaid A., El boulifi N., Hahati K., Martinez M., Aracil J. 2014. Biodiesel production from biobutanol. Improvement of cold flow properties. Chemical Engineering Journal, 238, 234-241. DOI: 10.1016/j.cej.2013.10.022.

3. Fjerbaek L., Christensen K.V., Norddahl B. 2009. A Review of the Current State of Biodiesel.

4. Production Using Enzymatic Transesterification. Biotechnology and Bioengineering, 102 (5), 1298-1315. DOI: 10.1002/bit.22256

5. Karavalakis G., Stournas S. and Karonis D. 2010. Evaluation of the oxidation stability of diesel/biodiesel blends. Fuel, 89 (9), 2483-2489. DOI: 10.1016/j.fuel.2010.03.041

6. Knothe G., Steidley K.R. 2007. Kinematic viscosity of biodiesel components (fatty acid alkyl esters) and related compounds at low temperatures. Fuel, 86 (16), 2560-2567. DOI: 10.1016/j.fuel.2007.02.006

7. Kumar M., Gayen K. 2011. Developments in biobutanol production: new insights. Appl. Energy, 22, 1999-2012. DOI: 10.1016/j.apenergy.2010.12.055

8. Makarevičienė V., Matijošius J., Pukalskas S., Vègneris R., Kazanceva I., Kazancev K. 2013. The exploitation and environmental characteristics of diesel fuel containing rapeseed butyl esters. Transport, 28(2), 158-165. DOI: 10.3846/16484142.2013.801364

9. Pullen J., Saeed K. 2014. Experimental study of the factors affecting the oxidation stability of biodiesel FAME fuels. Fuel Processing Technology 125, 223-235. DOI: 10.1016/j.fuproc.2014.03.032

10.Tan T., Lu J., Nie K., Deng L., Wang F. 2010. Biodiesel production with immobilized lipase: A review. Biotechnology advances, 28, 628-634. DOI: 10.1016/j.biotechadv.2010.05.012 